$\begin{array}{ll}\text { Italique } & \text { Italique } \\ \text { Poésie italienne de la Renaissance }\end{array}$

XI 2008

Varia

\title{
Reading Desportes through the Italians : Two Early Modern Readers' Responses
}

JoAnn DellaNeva

\section{(2) OpenEdition}

Journals

\section{Edizione digitale}

URL: http://journals.openedition.org/italique/208

DOI: 10.4000/italique.208

ISSN: 1663-4438

\section{Editore}

Librairie Droz

\section{Edizione cartacea}

Data di pubblicazione: 1 dicembre 2008

Paginazione: 29-52

ISBN: 978-2-600-01254-6

ISSN: 1423-3983

\section{Notizia bibliografica digitale}

JoAnn DellaNeva, «Reading Desportes through the Italians : Two Early Modern Readers' Responses », Italique [Online], XI | 2008, online dal 01 février 2012, consultato il 20 avril 2019. URL : http://

journals.openedition.org/italique/208 ; DOI : 10.4000/italique.208

(C) Tous droits réservés 


$$
\text { JoAnN DELLANEVA }
$$

REA D ING DESPORTES

THROUGH THE I T A L A N S :

T W O E A R L Y

M O D ER N REA D ER S'RES PON S E 



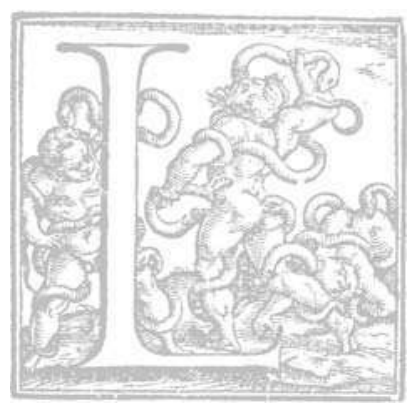

Ike most $16^{\text {th }}$-century French poets, Philippe Desportes made liberal use of the Italian lyric tradition as source material for his poems. These sources include not only Petrarch's canzoniere but also a host of more minor petrarchist poems, many of which Desportes no doubt read in the collections of Italian lyrics that were published throughout the Renaissance, including the well-known 9-volume set popularly referred to as the Giolito Anthologies, the Italian Anthologies, or the Rime diverse. 'That Desportes's early readers were cognizant of his predilection for imitating Italian models can be verified by the accounts of several commentators, including Antoine du Verdier, Henri Estienne, Etienne Pasquier, Guillaume Colletet, and, most famously, François de Malberbe, who alternately praised or condemned the Frenchman's use of these sources. ${ }^{2}$

In addition to these more formal and extensive critical statements, there are two unique, anonymous texts that, while not exactly "commentaries," nevertheless serve to signal Desportes's relationship to the Italian lyric tradition. One is a set of handwritten marginal annotations found in the I593 edition of Desportes's Oeuvres now housed in the Bibliothèque municipale of Lyon. ${ }^{3}$ The other is a small dual-language volume of poetry entitled the Rencontre des Muses de France et d'Italie, published in I604 by the same Lyonnais printer of Desportes's I593 collected works, Jaques [sic] Roussin. ${ }^{4}$ In each case, one of Desportes's poems is paired with an Italian counterpart. These two sets of reader responses thus provide a fascinating insight into how Desportes's near-contemporaries understood the integral relationship between reading and writing in the $t^{\text {th }}$ century. Moreover, their anonymity makes them all the more valuable as they appear to exemplify the response of everyday readers who were not necessarily professional literary critics. Not coincidentally, both sets of responses highlight, in different ways, the importance of the Italian anthologies in shaping French poetic practice of the Renaissance.

The anonymous handwritten marginal annotations found in the Lyon library have never been completely transcribed nor adequately analyzed. Accordingly, the appendix to this article gives a complete transcription of these annotations in the order in which they appear in Desportes's Oeuvres of 1593. Little is known of the provenance of this volume; there is no ex libris and, indeed, the original title page, where one might hope to find an indication of the book's ownership, is missing. According to the head curator of the rare book collection at Lyon, its call number suggests that this work was among those 
confiscated during the French Revolution from religious houses, though not necessarily from the Lyon area.' Nor can one say for certain when these annotations were written, except that they obviously postdate I602, because they make reference to the work of Marino published that year. However, as Joseph Vianey affirms in his incomplete study of this work published in I906, the handwriting style employed here makes it likely that these notes were penned in the early part of the seventeenth century, that is, by one of its early readers. Often the annotation is crossed out and therefore difficult to read. Still, enough information can be salvaged to assert that the annotator has recorded, in the margins surrounding exactly fifty poems, the names of twentyfour different Italian poets, along with a page number or poem number reference, signaling a parallel passage. ${ }^{6}$

Nowhere in these marginal notes does the name of Petrarch appear. Instead, we have a list of names that runs the gamut from the famous Bembo, through a number of other fairly well-known versifiers, such as Tebaldeo, Sannazaro, and Della Casa, to quite a few little-known figures, including Giacomo Cencio, Pietro Barignano, and Giovanni Battista Amalteo, not to mention one unknown soul listed under the rubric of Incerti autori (that is, "poems of uncertain authorship'). The most often cited name is that of di Costanzo, a poet whose somewhat flamboyant style was reminiscent of earlier, more extravagant Quattrocento poets such as Tebaldeo, who happens to be the second most often cited name in the margins. The vast majority of the notes clearly refer to poems contained in various anthologies, the manner of publication preferred by most Italian lyricists writing in the mid-I540s and beyond, who, by and large, chose not to arrange their poems in a canzoniere format. ${ }^{7}$ A few of the annotations, however, refer to the works of individual poets, namely Tebaldeo, Bernardo Tasso, Marino, Della Casa, and Berni. ${ }^{8}$ Thanks to the notation of a specific page number for many of the anthologized poems, it can be determined that this anonymous annotator had access to the second edition of the first volume of the Giolito anthology (Rime diverse di molti eccellentissimi auttori nuovamente raccolte. Libro primo, con nuova additione ristampato, published in I546 and reprinted with identical pagination in I549), the first edition of the second Giolito volume (Rime di diversi nobili huomini et eccellenti poeti nella lingua thoscana. Libro secondo, published in I547), and, most especially, I Fiori delle rime de' poeti illustri, nuovamente raccolti et ordinati da Girolamo Ruscelli of 1579 or its I586 reprint, a retrospective anthology first published, with different pagination, in I5) 8 by a rival of Giolito's but considered by bibliographers to be volume eight of the Giolito series.

Joseph Vianey has asserted that not all of these comparisons are valid and that many bear only a passing resemblance to each other. This explains why 
bis brief analysis focuses on only nine of the fifty annotations: for Vianey was interested solely in pointing out verifiable but previously unacknowledged Italian sources for Desportes's poems. Given the tenuous connection between some of these poems, it is not surprising that not all of these "sources" are noted in the most modern edition of Desportes's works, and indeed many of the French poems are noted to have a very different Italian source. Moreover, the references to poems by Marino cannot possibly be taken as an indication of Desportes's model, for the Italian's poetry was published after that of the Frenchman: the annotator is here merely pointing out an analogous passage. One might think that the annotations that are heavily crossed out perbaps indicate a change of heart regarding the source or analogue (though one does not know if the effacement was done by the original annotator or by a subsequent reader). But in several cases these paired poems are in fact very close indeed, making this hypothesis unlikely. Regardless of whether the annotation is effaced or not, it still might reveal a certain insight into how contemporary readers approached their reading of French poems through the plethora of Italian poetry available to them primarily through the Italian anthologies.

There are, among these annotations, seven different categories of relationships established between the French and Italian poems. That is, the annotator has defined the relationship by writing (I) the poet's name alone; (2) the poet's name preceded by the command voy or "see"; (3) the phrase imite de or "imitated from"; (4) the phrase prins de or "taken from"; (5) the long phrase ce sonnet est entierement pris de or "this sonnet is entirely taken from"; (6) the phrase tiré de or "drawn from"; and (7) the preposition del, meaning "of," and the only annotation category presumably written in Italian. ${ }^{9}$

The first two categories - that is, those that give only the name of the poet or that instruct the reader to "see" an Italian counterpart - are by far the most numerous among the annotations. These clearly make the weakest claim of a relationship, one that does not necessarily imply any degree of "indebtedness" on the part of Desportes. Not surprisingly, it is here that we find the name of Marino, whose poems constitute not a source but simply an analogue to Desportes's lyrics. It is also here where modern editors most frequently posit a different poem as a possible source and do not mention the poem signaled by our annotator. A case in point is Avoir pour toute guide (Hippolyte 43), where the Lyonnais annotator informs the reader to "see Pietro Barignano" while Desportes's modern editors find here an imitation of a poem by Bernardo Rota, Viver' altrui. ${ }^{10}$ But the lack of an explicit avowal of imitation on the part of the annotator does not always entail a weak relationship between the French sonnet and its Italian parallel. For it is sometimes the case 
that Desportes has in fact closely imitated the noted model, even if such a close imitation is not explicitly asserted by the annotator. Such is the case, for example, with the poem Soucy chaud (Hippolyte 68), where the annotator simply writes the words "Gio. Della Casa son 8》 signaling a sonnet which modern editors and readers have found to be a very close model indeed for the French text. ${ }^{\text {I }}$

On the other hand, the annotations that explicitly allege a deliberate imitation on the part of Desportes are fairly rare and amount to only I/s of the pairings. Only three poems are designated with the strongest assertion that the sonnet is "entirely taken" from an Italian source (namely, Tansillo, Amalteo, and B. Tasso), though one of these annotations - referring to Amalteo - has been subsequently very heavily crossed out and is barely legible. Three additional poems are listed as being "imitated from" di Costanzo, Guidiccioni and Molza; two others are noted as being "taken from" di Costanzo and yet another from Sannazaro; one is noted as being "drawn from" Caro, and still another is noted to be "of" Berni. These eleven texts are doubtless among the poems that bear the most striking formal resemblance to their Italian model, most often by having the same thematic development throughout and frequently by echoing the incipit in some fashion or recalling specific imagery and rbyme words. An example of this close imitation can be seen by comparing Desportes's La garnison d'ennuis, published as sonnet 47 in the poems for Cléonice, with Tansillo's sonnet, È sì folta, published in the Fiori. According to the Lyonnais annotator, Desportes's poem was "entirely taken from" Tansillo's sonnet:

Desportes, Cléonice 47:

La garnison d'ennuis, qu'Amour fait demeurer

En mon cœur pour sa garde, est si grande ey si forte

Qu'il ne faut avoir peur qu'un seul soupir en sorte,

$\mathrm{Ne}$ qu'il puisse en ses maux seulement respirer.

Si quelque heureux plaisir se veut avanturer

D'approcher de mon cœur, à fin qu'il le conforte,

Il esprouve à son dam qu'il se faut retirer:

Car s'il veut passer outre, on le tuë à la porte.

Le desespoir sanglant capitaine inhumain,

Sans jamais se lasser, tient les clefs en la main,

Et ne fait rien entrer que du parti contraire.

Tous pensers gracieux il en a sceu bannir,

Mes esprits seulement n'oseroyent s'y tenir,

S'ils n'estoyent affligez et comblez de misere.

Tansillo, Fiori 2 I $6 \mathrm{r}$

È sì folta la schiera de' martiri, 
Che in guardia del mio petto ha posti Amore,

Che è tolto altrui l'entrare, e l'uscir fuore,

Onde si moion dentro i suoi sospiri.

S’alcun piacer vi vien, perché respiri,

A pena giunge a vista del mio core,

Che, dando in mezzo de' nemici, o more

O bisogna che 'n dietro si ritiri.

Ministri di timor tengon le chiavi,

E non degnano aprir, se non a messi

Che mi rechin novella che m'aggravi.

Tutti i lieti pensieri in fuga han messi,

E se non fosser tristi, e di duol gravi

Non v'oseriano star gli spirti stessi.

This side-by-side reading shows that Desportes indeed initiated few changes in the overall thematic development and imagery of his model, one that would make its recognition as a source relatively easy for French readers acquainted with this Italian anthology. Not surprisingly, Desportes's modern editors are most often in agreement with the anonymous Lyonnais annotator with regard to the Frenchman's deliberate and close rewriting of these Italian texts.

But it is those cases where modern editors (and scholars) disagree with the Lyonnais annotator - that is, precisely the relationships that Vianey did not explore - that might prove to be the most fruitful subject of analysis. Indeed, it can be said with certainty that the anonymous reader of the Lyonnais volume clearly does not point out only the most blatant instances of imitation: Vianey had suggested so much by casting aside all but a handful of the parallels noted in the Lyonnais volume as worthy of his consideration. Such a restricted view, however, does not allow for the possibility that Desportes's contemporary readers might well have been cognizant of a wider range of ways in which poems can relate to each other. A close examination of these intertextual pairings reveals that the Lyonnais annotator was often struck by Desportes's reuse of individual units of material - a single startling image, an arresting turn of phrase - rather than simply a sustained rewriting of an entire sonnet. $A$ case in point is the poem Les premiers jours (Diane $I$ : 48), where the annotator instructs the reader to «see Angelo di Costanzo page $7 B$ » a reference to the poem Novo pensier, published in the Fiori. Desportes's modern editors see here a rewriting of a different Italian poem, one by Pamphilo Sasso, and do not mention di Costanzo. However, a side-by-side comparison of the sonnets of di Costanzo and Desportes shows just how sensitive the anonymous annotator was to the varieties of imitative practice in the sixteenth century: 
Desportes, Diane I, 48

Les premiers jours qu'Amour range soubs sa puissance

Un cœur qui cherement garde sa liberté

Dans les filets de soye il le tient arrêté

Et l'esmuet doucement d'un feu sans violence;

Mille petits Amours luy font la reverence;

Il se bagne en liesse et en felicité;

Les Jeux, la Mignardise, et la douce Beauté

Vollent tousjours devant, quelque part qu'il s'avance.

Mais, las! presque aussi tost cet heur se va perdant;

La prison s'etrecist, le feu devient ardant,

Les filets sont changez en rigoureux cordage.

Venus est une rose espanie au Soleil,

Qui contente les yeux de son beau teint vermeil,

Mais qui cache un aspic sous un plaisant feuillage.

Angelo di Costanzo, Fiori ( 1579 ) $7 \mathrm{r}$

Novo pensier, che con sì dolci accenti

Meco ragioni, e, promettendo al core

Quanta gioia ad alcun mai diede Amore,

Di far tornarmi in servitù ritenti.

Io, che per prova so quanti tormenti

Mesce nel dolce suo l'empio Signore,

Non ardisco seguirti, e col timore

Fermo i miei spirti ad ascoltarmi intenti.

E quanto con più vivi e bei colori

Mi pingi adorno quel celeste aspetto,

D'alta bellezza e di pietà di fuori,

Tanto maggiore in me cresce il sospetto

Che raro in prato pien di vaghi fiori

Aspe non è d'atro veneno infetto.

It is clear that the only way in which Desportes's poem resembles its Italian counterpart is in the image of the bidden asp found at its final verse or pointe, an image that corresponds to di Costanzo's similar image of the proverbial snake in the grass, also found in the poem's final verses. The similar sounds of the French word aspic and the Italian aspe reinforce this correspondence.

This lone resemblance, which critics such as Vianey and Desportes's modern editors might summarily dismiss, is nevertheless significant enough to the anonymous Lyonnais annotator. For this reader saw that Desportes sometimes scoured the Italian anthologies for suggestive sounds and images that could be removed from their context and subtly reworked into his own poem. In 
other words, this reader realized that imitative poets could use the Italian anthologies much as they would a commonplace book, or indeed the many published concordances of Petrarch's rbymes, epithets, and images that systematically broke down and codified that text into bundreds of discontinuous and recombinable parts that need not carry any vestige of their original context. ${ }^{12}$ Amedeo Quondam has described how Petrarch's text was indeed frequently anatomized, that is, reduced to its constituent parts (rbymes, images, etc.) in manuals destined for prospective writers who could then reuse these raw materials to fabricate virtually any new text they could imagine. ${ }^{{ }^{3}}$ Certainly, if Petrarch's well-wrought and intricately fashioned canzoniere could be subjected to such fragmentation, then the Italian lyric anthologies would be even better-suited to this piecemeal imitation. This is because, like the commonplace book and published concordances, the anthologies already constituted a collection of disparate, disconnected discourse that vividly contrasts with the sustained sequence of poems that make up a canzoniere, such as Petrarch's Rime sparse. ${ }^{14}$ Such discontinuous and, indeed, uneven texts (with regard to their quality) surely invite, by their very nature, the imitation of individual units of exemplary speech to the exclusion of less noteworthy elements in the sequence of poems. This anonymous Lyonnais reader thus recognized that Desportes's imitations of Giolito anthology poems need not always follow their model closely, mirroring their thematic development. Instead, they could betray a distant affiliation to a subtext merely by repeating a single, eye-catching image (and, frequently, its sound) torn from its original context.

The second anonymous annotator of Desportes's sources, the author of the Rencontre, produced a far more elaborate statement on this subject that has received a bit more attention from modern critics. The anonymous author first provides a dedication to the current French Queen, Marie de Médicis, where he reveals that he has discovered a series of poems by famous Italians and an unnamed Frenchman that each recount, in remarkably similar terms, the stories Love has dictated to them. These coincidences might be explained by the fact that the two authors were inspired by the same "genius" or "enthusiasm," namely the fury of love. ${ }^{15}$ But despite this ostensible nod to individuality and originality, it is very clear that the reality of the situation is that the French poet was not inspired by some vague Genius, or god of Love, but rather by the myriad sonnets he found printed in various Italian anthologies and collections of poetry. Of course, the author of the Rencontre knew this full well, and his multiplication of examples quickly dispels any sense that coincidence might have played a role here.

The volume's dedication to the native Italian Marie de Médicis might thus be explained as a Frenchman's acknowledgment that his country's best poetry owed much to the queen's motherland, a fact that she could reasonably be 
expected to embrace with great pride. Moreover, given his tongue-in-cheek tone, it seems that the anonymous author of the Rencontre might also have wished to embarrass the court poet Desportes by revealing the sources of his inspiration, or the secrets of his success. Certainly this is how contemporary readers interpreted the Rencontre. It is reported that, when shown this anonymous volume by someone presumably hoping for a denial or a justification, Desportes merely shrugged off the implicit accusation of plagiarism, saying that, had he been in consulted, he would have pointed out many more resemblances. ${ }^{16}$

But a complete and fair evaluation of the anonymous author's intent cannot depend simply on the words of this dedicatory letter. Rather, this can be accomplished only by an extensive analysis of the contents and structural organization of the work itself. The Rencontre constitutes a bilingual volume containing forty-three pairs of poems. On the left hand page, a poem (most often a sonnet) by Desportes (who is identified in the table following the preface only as «M. D. P.») is transcribed, while on the right hand page an analogous Italian poem - Desportes's putative source - is printed. But unlike the Lyonnais annotations, however, none of these pairs is explicitly described in terms of source or model, whereby the French poet is presumed to have deliberated "imitated," "taken from" or "drawn from" an Italian source. Rather, the twinned poems here are simply placed side by side in a manner that is more suggestive of intertextual studies (which is not concerned with the role of the author as an agent of imitation) than imitative studies (which posit an active writer who deliberately chooses to rewrite and reuse previous texts, as Renaissance literary treatises would have counseled). ${ }^{17}$

These pairs of poems are uniformly extremely close in thematic development, though there are, of course, many variations in detail. Desportes's poems are not identified by collection and none of the Italian sonnets bears the name of its author, once again suggesting the anonymity of intertextual studies avant la lettre. However, the table following the preface indicates that the Italian authors are Angelo di Costanzo, Antonio Tebaldeo (spelled "Tibaldeo" as was customary in his early collections), Bernardo Tasso, Bernardino Tomitano, Dominico Veniero, Francesco Maria Molza, Giovan Mozzarello, Giacomo Sannazaro, Gio. Bat. Amaltheo, Gio. Andrea Gesualdo, Gio. Iacomo Dal Pero, Girolamo Parabosco, Luigi Tansillo, L'Amanio, and Remigio Fiorentino. This motley group represents a mixture of some fairly famous poets and some virtually unknown versifiers, who are, with the exception of "L'Amanio», listed alphabetically by first name, just as they are in a typical tavola of the Italian anthologies. ${ }^{\mathrm{I}}$ Since these names are not attached to any given text, it is presumably up to the reader to discover who has authored each Italian source poem. 
The impulse to match poems with their author is no doubt a strong one for most readers, and, indeed, this work was accomplished long ago by Francesco Flamini, who painstakingly paired the names of the Italian authors with their respective texts. ${ }^{19}$ He also noted where these poems had been published, using the 1558 edition of the Fiori, the I549 edition of the first Giolito anthology, the 1547 edition of the second Giolito volume, and a few independent volumes of poetry by individual authors, such as Tebaldeo. Flamini's considerable effort was an invaluable aid to the tracking of sources, but one can take issue with his assertion that those volumes were the ones most likely to have been used by Desportes himself (or, for that matter, by the compiler of the Rencontre). Indeed, had Flamini looked at the complete Italian poems in each case, he would have noticed that some of these texts had multiple variants published in different volumes and that the Rencontre editor was clearly following one volume in preference to the others. The list in appendix two consequently modifies Flamini's study somewhat.

Judging from this new list, the most frequently used anthology on the part of the Rencontre editor was clearly the Fiori, and this is no doubt a reflection of Desportes's own poetic tastes. It is not possible, however, to discern which particular edition of the reprintings of the Fiori served as the compiler's source, for the texts within these multiple editions are printed without change, though with different pagination. One can say for certain, however, that, like the Lyon annotator, the Rencontre editor used the first edition of the second Giolito volume (published in I547) and not its I548 reprinting, because the poem given as sonnet three was attributed to Amanio (listed in the Rencontre's table of authors) only in that first edition. ${ }^{20}$ Consequently, the anonymous author probably also thought that s. 36, the poem $\mathrm{O}$ d'humana beltà, was written by Cencio and not Caro, as was actually the case and corrected in the I548 reprinting. Curiously, however, neither the name of Cencio nor Caro appears in the table of the Rencontre. One might take this as a reflection of the disputed attribution of Caro's poem, were it not for the fact that the Rencontre contains a second poem by Caro, though its incipit is mysteriously transcribed not as as Egro già but as Carco già, a form that is not found in any Renaissance volume. It is likely, then, that the incipit Carco già is simply a typographical error, one that might have been prompted by interference from Desportes's actual French incipit, Chargé de or perhaps even from the name "Caro» itself. It is also clear from a study of the variants that the Rencontre author did not draw from the Giolito anthology volumes numbered 5, 6, and $7 .{ }^{21}$ Yet, though he frequently uses the Fiori elsewhere, the Rencontre compiler nevertheless drew his transcription of sonnet 5, Mozzarello's $\mathrm{O}$ bella man, not from the Fiori but rather from the first Giolito volume, as demonstrated by the variants he uses. ${ }^{22}$ 
In addition to these volumes in the Giolito series, the Rencontre editor possibly also made use of another Italian anthology, titled De le rime di diversi nobili poeti toscani and published by Dionigi Atanagi in I565, instead of the independent volume, the Rime di Francesco Coppetta di Beccuti (I580), as Flamini claimed. ${ }^{23}$ This can be established by comparing a transcription of the Italian s. 40, Locar sovra, as it appears in the Rencontre, with the version that was printed in Coppetta's Rime and in the Atanagi anthology. The compiler's version is certainly closer to, though, curiously, not identical with, the Atanagi version and shows significant differences from the Rime version. There is no doubt, however, that it is this anthologized version that Desportes knew, as his virtual translation of Coppetta's verse nine, which differs from theI580 Rime version, makes clear: ${ }^{24}$

From Atanagi anthology ( 565 )

Locar sovra gli abissi i fondamenti

De l'ampia terra; \& come un picciol velo

L'aria spiegar con le tue mani; e 'l cielo,

Et le stelle formar chiare, \& lucenti;

Por leggi al mare, a le tempeste, a' venti

L'humido unire al suo contrario, e 'l gelo;

Con infinita providenza, \& zelo

Et creare, \& nudrir tutti i viventi,

Signor, fu poco a la tua gran possanza

Ma che tu re, tu creator volessi

Et nascer, \& morir per chi t'offese,

Cotanto l'opra de' sei giorni avanza,

Ch'io dir nol so: nol san gli angioli stessi

Dicalo il Verbo tuo, che sol l'intese.

Desportes, Sonnets spirituels 7

Sur les abysme creux des fondemens poser

De la terre pesante, immobile \& feconde,

Semer d'astres le Ciel, d'un mot créer le monde,

La mer, les vents, la foudre à son gré maistriser

De contrarietez tant d'accords composer,

La matiere difforme orner de forme ronde,

Et par ta prevoyance en merveilles profonde,

Voir tout, conduire tout, \& de tout disposer,

Seigneur, c'est peu de chose à ta majesté haute:

Mais que toy, Createur, il t'ait pleu pour la faute,

De ceux qui t'offensoyent en croix estre pendu,

Iusqu'à si haut secret mon vol ne peut s'estendre,

Les Anges, ny le Ciel ne le sçauroyent comprendre,

Appren-le nous, Seigneur, qui l'as seul entendu. 
Flamini's probable misidentifications of the exact publication from which the Rencontre editor drew serve as a reminder to those of us dealing with imitation matters in French Renaissance poetry - particularly after I550that our poets often had at their disposal several alternative versions of a given text which appeared in many different volumes. What we might mistakenly take for an innovation on the part of our French poet might well be a faithful rendition of a variant of which we are ignorant.

Further study of the complete chart of corresponding poems in appendix two reveals much other information. First, there is quite a bit of overlap between the Rencontre sources and the anonymous Lyonnais annotation. Both the Rencontre editor and the Lyonnais annotator have (presumably) independently recognized twenty different sources from such second-tier poets as Mozzarello, Veniero, Tansillo, B. Tasso, Guidiccioni, Amalteo, Caro or Cencio, and especially di Costanzo (as well as from Tebaldeo). Surely the fact that two different readers could find so many different sources from the Italian anthologies bere is a testament to their enduring popularity at the turn of the seventeenth century, even though these anthologies had ceased to be republished by this time. Moreover, one notices that the list of Italian authors inscribed in the Rencontre's table of contents does not fully agree with the actual identification of the sources in appendix two. There is no poem here by Sannazaro, who is listed in the table, while there are instead two poems by Caro and one each by Guidiccioni and Coppetta, who are not listed there. There is simply no good accounting for these discrepancies. It is not the fact, for example, that any of the poems contained in this volume was wrongly attributed to Sannazaro or that the poems by Caro, Guidiccioni, and Coppetta were attributed to another poet whose name does appear in the tavola. One can conclude only that, as was often the case in the Giolito anthologies themselves that are replete with mistaken attributions, identifying the authors of these poems was not a bigh priority for the editor of the Rencontre. Indeed, had it been so, one would have expected the names of the poets to appear on each page.

Instead, these poems are presented as if they were anonymous products, precisely as they often appear on the pages of the Italian anthologies which, with the singular exception of the Fiori, did not print headers with the names of the poets on every page. The effect of this typographical layout is that, in flipping through the pages of any anthology volume, one can read a poem without necessarily knowing by whom it was written. Even when reading the poems page by page in sequence, a reader could easily forget the name of the author, particularly one with a very large selection of poems in the anthology. Ironically, the only authors who are spared this sense of anonymity are those mostly amateur (and frequently mediocre) poets who had only a single poem or two printed in the volume, which would naturally appear immediately after 
their name. Thus, in the way it deals with the names of the Italian poets - by its table listing the poets in alphabetical order by first name, by its lack of beaders on every page assigning the poem to a single author, and by the way it sometimes fails to credit poems to their rightful authors - the Rencontre mirrors many of the publishing idiosyncrasies of the Italian anthologies.

But another feature to consider in evaluating this volume is the arrangement of the poems within the collection, and it is here that perhaps the most interesting aspects of the Rencontre come to light. The ordering of poems in this text appears, at first glance, to be random, for the texts clearly do not follow the alphabetical order of the introductory table, nor are all the poems taken from the same Italian source placed together. Similarly, the French poems are certainly not arranged in their order of publication within Desportes's works. The only exceptions to this observation appear towards the end of the collection, where poems from the Epitaphes and Sonnets spirituels are clustered. Yet it is precisely this anomaly that provides the first hints that the structure of the Rencontre is surely not at all haphazard. For these poems, with their emphasis on death and penitence, are highly reminiscent of the final one hundred poems of Petrarch's Rime sparse. Indeed, with that in mind, if one reads the French poems or their Italian counterparts in succession, it is clear that the anonymous author of the Rencontre has, in fact, created not another anthology, as we might have been inclined to believe, but rather a canzoniere that is modeled on Petrarch's masterpiece as well as some of its many imitations. If composing a canzoniere were the actual goal, this would provide an alternate explanation for the apparent anonymity of the Italian poems in the collection: for the compiler would naturally have wanted to help the reader to forget that he or she was reading the individual compositions of various poets by giving the illusion that they are, in effect, all of a piece.

What distinguishes the canzoniere genre from the anthology is not only the unanimity of its authorship but also its overarching narrative structure. Petrarch's Rime sparse, the prototype of this genre, relates the story of the lover's passion for a single woman. It recounts the moment of the innamoramento and documents the progress of this extraordinary love affair that took place over a period of twenty-one years until the death of the beloved lady is revealed. In the final one bundred poems, the lover narrates his decision to turn away from his earthly passion and redirect his desires toward salvation, much as St. Augustine portrayed his conversion in the prototypical autobiography, The Confessions. This narrative aspect of the Rime sparse might be even more easily perceived by Renaissance readers who read their Petrarch in a commentary edition: for many commentators were quick to point out the "story line" of the canzoniere, often summarizing the "action" of preceding poems with each new annotation. ${ }^{25}$ 
A careful reading of the Rencontre reveals a remarkably similar structure. The first two sonnets in the sequence are appropriately self-referential, treating the theme of the poet's difficulty in singing of his inexpressible emotions and his beloved's ineffable beauty (I-2). The next poems (3-7) begin to describe the lady's physical features, often focusing on a particular body part such as the eyes or hand, in the manner of a blason. There follows (in poems 8-24) a series on the poet's suffering and the lady's concomitant cruelty. Among the lover's torments are his insomnia and illusory dreams (25-27). The poet thereupon continues (in poems 28-33) to treat the theme of his suffering, in particular his regret for having spent his time vainly wooing this cruel lady, hinting that he has had enough of this and will turn away from this foolish pursuit. A moment of crisis occurs (in 34-35) when a rival is introduced who marries the lady. But her removal from the lover is merely a foreshadowing of a more sinister absence, one that is brought about by the lady's untimely death (36-37). With his angelic lady gone, the lover turns to God in a spirit of repentance towards the end of his own life (38-42). Finally, just as Petrarch's final canzone addressed the Virgin Mary, so too does the final poem of the Rencontre (43) allude to another biblical Mary, the woman who anointed Christ with oils, whom St. John the Evangelist identifies as Mary of Bethany but who in traditional iconography has been conflated with Mary of Magdala, popularly (though inaccurately) portrayed as a repentant prostitute. By ending his canzoniere with a different Mary, while still maintaining the theme of penitence, the editor of the Rencontre can at once recall his Petrarchan model while providing a new variation on that work.

The Rencontre des Muses thus has a strong narrative thread, forming a coherent sequence of poems in the manner typical of the canzoniere format. Instead of creating an anthology of disparate pieces, it draws freely from Desportes's many poetic collections, treating them all as if they were in fact merely anthologies from which one could select suitable fragments to be reworked into a new composite whole. In so doing, the anonymous editor of the Rencontre mirrors or mimics the work of Desportes and other poets who culled from the Italian anthologies in designing their own canzonieri. Like the anonymous Lyonnais annotator, this editor also exbibits an implicit understanding that the Italian anthologies were used as sourcebooks containing a variety of reusable fragments. By while the Lyonnais annotator emphasized the reuse of small fragments within a single sonnet, the editor of the Rencontre understood this fragmentation more globally, for he saw that individual whole poems could be recombined in an infinite number of ways to create a completely new work, as the Rencontre itself, a newly minted canzoniere in its own right, helps to prove. 
It is true that a few "mini-canzonieri" have been discerned within certain anthologies; that is, the sequence of poems under the rubric of a single author in some cases also mimics the structure of a canzoniere. ${ }^{26}$ Erika Millburn, for example, has described the sequence of Tansillo's poems in Giolito's Libro terzo as just such a mini-canzoniere, whereby poems I-9 celebrate love and the lady, IO-I3 introduce the departure of the poet, I4-I7 deal with the theme of jealousy, I8-2I treat the lover's disdain and renunciation of love, and 22-23 show his religious conversion. ${ }^{27}$ This pattern is similar to the one reconstructed by the Rencontre editor, except that the latter also includes the recounting of the death of the beloved, which is not present in Tansillo's poems. But the existence of these mini-canzonieri in no way diminishes the novelty of the Rencontre's format, since such narrative patterns have been discerned only among the works of a single poet and are not displayed in the succession of poems by different authors throughout an anthology. Nevertheless, it is certainly possible that the Rencontre editor recognized this interplay between the anthology and canzoniere formats and that this recognition prompted bim to experiment with yet another possible intersection of the two beretofore distinct genres.

In sum, it appears that two anonymous readers of Desportes - the Lyonnais annotator and the editor of the Rencontre - independently reached similar conclusions regarding bis relationship to the Italian lyric tradition. The Lyonnais annotator recognized that Desportes's imitations ranged from the sustained to the fragmentary, from the obvious to the subtle. Cognizant of the inherent discontinuity of the anthology format, this reader no doubt knew that French poets, from Du Bellay to Desportes, found in the Giolito anthologies a treasure trove of images, conceits, and rbymes that could easily be disengaged from their original context and placed in a new poem, even one with a very different thematic development. The compiler of the Rencontre, on the other band, implicitly acknowledges that French authors throughout the sixteenth century persisted in composing canzonieri, a genre that their Italian neighbors had largely abandoned in favor of publishing their poems in an anthology format. Yet he also saw that, in organizing these canzonieri, French poets drew from the Italian anthologies, reshaping their disparate pieces in new ways and using them as building blocks with which to construct their own personal narrative. In this way, the Rencontre des Muses is far more than a sly device created to show just how derivative Desportes's verses really were. More pertinently, this collection recreates the imitative process used by Desportes bimself, demonstrating its inherent creativity, and especially proclaiming the pivotal role of the Italian anthologies as a sourcebook for Renaissance poets.

JoAnn DellaNeva 


\section{Reading Desportes through the Italians}

A version of this paper was read at the Sixteenth Century Studies Conference in Salt Lake City, October 2006. I am grateful to those in attendance for their helpful comments on that earlier draft. This research was supported by funding from the Institute for Scholarship in the Liberal Arts at the University of Notre Dame, which I gratefully acknowledge. I should also like to thank Michel Jeanneret for his gracious permission to consult the impressive collection of rare books of the Fondation Barbier-Mueller pour l'etude de la poésie italienne de la Renaissance in Geneva.

I. For more on the complicated publication history of these anthologies, which were originally published during the period I545-1560 with numerous subsequent editions, consult Louise George Clubb and William G. Clubb, Building a Lyric Canon: Gabriel Giolito and the Rival Anthologists, I545-I560, «Italica», 68 (1991), pp. 332-44 as well as Pilar Manero Sorolla, Antologías poéticas italianas de la segunda mitad del Siglo XVI (I545-I590), «Annuario de filologia», (1983), pp. 259-99. For an encyclopedic study of the Giolito press, consult Angela Nuovo and Christian Coppens, I Giolito e la stampa nell'Italia del XVI secolo, Geneva, Droz, 2005 .

2. See Antoine du Verdier, La Bibliothèque ( 585 ); Henri Estienne, De la precellence du langage françois (i 579); Etienne Pasquier, Les Recherches de la France (i 560 ), Guillaume Colletet, Traité du sonnet and Discours de l'Eloquence et de l'Imitation des Anciens (I6;8). The copy of Desportes's Premières oeuvres (1600) with Malherbe's handwritten annotations is housed in the Bibliothèque Nationale de France (Rés. Ye 2067) and can be consulted on-line via the BNF's digitized collection, GALLICA.

3. See the Oenvres de Philippes DesPortes (Lyon: Jaques [sic] Roussin, I 593), Lyon BM Rés. 800728. This work was described in Joseph Vianey, Une Rencontre des Muses de France et d'Italie demeurée inédite, «Revue d'histoire littéraire de la France», I 3 (1906), pp. 92-100.

4. This rare work, housed in the Bibliothèque Nationale of Paris (Rés. Y 48I9), was described by Francesco Flamini in Le Rime di Odetto de la Noue e l'Italianismo a tempo d'Enrico III and I Plagi di Filippo Desportes, both in Studi di storia letteraria italiana e straniera, Livorno, Giusti, I 895, pp. 34I-8I and 43 I-39. The Rencontre can now be consulted on-line through GALLICA, the digitized collection of the BNF.

5. I am very grateful to Yves Jocteur-Montrozier of the Bibliothèque Municipale of Lyon for sharing his expertise on this matter with me and for the hospitality the library staff bestowed on me while working on this project.

6. These poets are Veniero, Tebaldeo, di Costanzo, Domenichi, Marino, Guidiccioni, Mozzarello, Sannazaro, Rainieri, an «incerto autore», Barignano, Navagero, Bernardo Tasso, Della Casa, Colonna, Molza, Amalteo, Tansillo, Tomitano, Berni, Cencio, Caro, Martelli, and Bembo.

7. For more on the demise of the canzoniere genre, consult especially Roberto Fedi, Il genere letterario dei 'canzonieri' ed i 'libri di rime' nel Cinquecento italiano, in Italian Renaissance Studies in Arizona, eds. Jean R. Brink and Pier Baldini, River Forest, IL: Rosary College Italian Studies, I 989, pp. 29-4I and, by the same author, La memoria della poesia: Canzonieri, lirici e libri di rime nel Rinascimento, Rome, Salerno, I990; see also Stefano Bianchi, Un manoscritto autografo di rime di Francesco Maria Molza ed una piccola raccolta a stampa del 1538 , «Filologia e critica», 17 (1992), pp. $73-87$, especially p. 83 .

8. Tebaldeo's work predates the Italian anthologies, Marino's postdates them, but Della Casa and B. Tasso were published in some anthologies. Berni's poem is a long narrative text that would not have been suitable for inclusion in the Italian lyric anthologies. It is known, however, that Desportes owned a copy of Tutte le opere di Francesco Berni in terza rima ( 1545 ). 
See on this point Isabelle de Conihout, Du nowveau sur la bibliothèque de Pbilippe Desportes et sur sa dispersion, in Philippe Desportes (I546-1606), Un poète presque parfait entre Renaissance et Classicisme, ed. Jean Balsamo, Paris, Klincksieck, 2000, pp. I 2 I-60. When referring to works other than the anthologies, the annotator usually gives the poem number rather than page number, making it impossible to determine which edition he (or she) was using.

9. It is possible that the annotator might have meant to write the preposition «dal», meaning "from", but didn't realize that "of" and "from" are rendered differently in Italian as they are not in French. Indeed, given the occasional misspellings that occur in the notes (e.g., "sonnetto» for "sonnet" or "sonetto"), it is fairly clear that the annotator was a native speaker of French who dabbled in Italian and was sometimes confused by similarly spelled words. But, in this case, the preposition «del» is most likely part of the Italian title of the work to which the annotator is referring, «La Caccia d'amore del Bernia».

io. See on this point Philippe Desportes, Les Amours d'Hippoltye, ed. Victor E. Graham, Geneva, Droz, 1960, p. 89, n. I.

i i. See Desportes, Hippolyte, ed. Graham, p. i2s, n. I.

I 2. For an example of these types of manuals, printed as an appendix to the Rime sparse, see Il Petrarca novissimamente revisto, e corretto da messer Lodovico Dolce. Con alcuni dottissimi avertimenti di M. Giulio Camillo, et Indici del Dolce de' concetti, e delle parole, che nel Poeta si trovano, \& in ultimo de gli epitheti; \& un utile raccoglimento delle desinenze delle Rime di tutto il Canzoniere di esso Poeta, Venice, Giolito, I 554. For an example of a rimario that was printed in France, and of which Desportes would certainly have been aware, see the Tavola di tutte le rime de i sonetti e canzoni del Petrarca ridotte co $i$ versi interi sotto le lettere vocali by Luc'ANTONIO Ridolfi, which was appended to several Lyonnais editions of Petrarch (published in I 550 , I 55 I, I 558 , I 564 , and 1574 by Guillaume Roville). For a general discussion of the Renaissance use of commonplace books, consult Ann Moss, Printed Commonplace-Books and the Structuring of Renaissance Thought, Oxford, Clarendon, 1996.

13. See Amedeo Quondam, La lirica e la tradirione, in Il Naso di Laura: Lingua e poesia lirica nella tradizione del classicismo, Modena, Panini, I991, pp. I 3-44, where the author states of the works of Boccaccio and Petrarch that «il loro corpus testuale viene segmentato in una topica in grado di proporre i suoi materiali (non solo linguistici) come complessiva fabrica del mondo, d'ogni comunicazione possibile, d'ogni testo a venire» (p. 38). See also Quondam's Dall'abstinendum verbis alla 'locuzione artificiosa': Il Petrarchismo come sistema linguistico della ripetizione, in Il Naso di Laura cit., pp. I8 I-99, where the author declares that «il petrarchismo istuisce un'economia combinatoria senza limiti del modello Petrarca: la sua è compiutamente la fabrica del mondo, che consente a tutti di costruire scrittura, con più o meno sapienti prelievi, riusi, montaggi delle sue parole-pietre» (p. I 85). In both instances, Quondam is alluding to FRANCESCO AlunNo's La fabrica del mondo, a concordance that reproduces all the words and rhymes of Petrarch (and Boccaccio) first published in I 548 (in actuality, an amalgam of Alunno's earlier Le Osservazioni sopra il Petrarca of I 539 and Le richezze della lingua volgare sopra il Boccaccio of 1543 ).

I4. On this point, see Guglielmo Gorni, Le forme primarie del testo poetico, in Letteratura italiana: Le forme del testo: Teoria e poesia, vol. 3, pt. I, ed. Alberto Asor Rosa, Turin, Einaudi, 1984, pp. 504-8. Gorni maintains that the Italian anthologies constitute «volumi miscellanei che attuano un progetto opposto a quello a cui s'ispira un libro organico di poesia; che affermano le ragioni della crestomazia, del frammento, dell'esemplarità, contro quelle della lettura continua, della coesione interna, della contestualità» (p. 505). Franco Tomasi likewise suggests how Italian lyric anthologies could serve as a kind of «strumento di lavoro al pari di rimari e vocabolariy; see on this point his introduction to the modern edition of the Rime diverse di molti eccellentissimi autori (Giolito I545), eds. Franco Tomasi and Paolo Zaja, San Mauro Torinese, Edizioni Res, 200I, p. XLI, n. 82. 
I 5. The dedication reads: «Ceux qui s'entendent en la difference \& condition des esprits, s'esmerveillent que plusieurs à l'insceu l'un de l'autre ayent descrit mesmes choses en mesmes conceptions, \& le plus souvvent avec semblables paroles, \& n'ent trouvent autre occasion, sinon qu'ils estoyent conduits de mesme Genie, \& poussez d'un mesme enthousiasme. Le fortuné rencontre que j'ay descouvert entre les plus fameux Poëtes Italiens, \& un Cigne François, sur le suject qu'Amour luy-mesme leur avoit dicté, en l'emulation qu'ils ont dés longtemps pour le prix de l'Eloquence, en peut rendre asseuré tesmoignange».

16. For this anecdote, see Vianey, Le Pétrarquisme en France au XVI siècle, (1909), Geneva, Slatkine Reprints, 1969, pp. 224-25. Colletet likewise refers to this incident: «Desportes, [...] dans ses Sonnets, aussi bien que dans ses autres Poësies diverses, enrichit nostre langue Françoise des riches dépoüilles de l'Italie. Ce qui est si vray, que fort peu de temps avant sa mort, il vid avec quelque sorte de déplaisir, un Livre contre luy, qui portoit pour titre: La confomité des Muses Italiennes et Françoises; où plusieurs de ses Sonnets François, traduits où imitez, estoient d'un costé, et l'original des Sonnets Italiens de l'autre». See Colletet, Traitté $d u$ sonnet, ed. P.A. Jannini, Geneva, Droz, 1965, p. i67. Clearly Colletet thought this volume was intended to embarrass Desportes.

17. For a discussion of authorial agency (or lack thereof) and the theories of intertextuality promulgated by Julia Kristeva and others, see Susan Stanford Friedman, Weavings: Intertextuality and the (Re)Birth of the Author, in Infuence and Intertextuality in Literary History, eds. Jay Clayton and Eric Rothstein, Madison, WI, The University of Wisconsin Press, 1991, pp. I46-80.

I 8. This important detail regarding the ordering of names in the table was missed by Flamini, who implied that the names were «citati confusamente a principio delle Rencontres» (p. 350).

19. It should be noted that this task has been greatly facilitated today by the on-line database created by the University of Pavia, ALI RASTA: Antologie della Lirica ItalianaRaccolte a stampa $<<$ http: //rasta.unipvit $/>>$.

20. The I 548 edition attributes this poem to «L'Unico Aretino» (that is, Bernardo Accolti).

2I. In s. 2 by di Costanzo, for instance, the editor of the Rencontre transcribes v. 9 as «Tal che (non potend'altro)», which is found in the Fiori, while it is rendered «Onde non potendo altro» in the fifth Giolito volumes of I 552 and I 555 , as well as the Rime scelte. Similarly, the sixth Giolito volume can be eliminated thanks to the fact that $\mathrm{s} .29$ by Tomitano gives, as a reading of v. I 2, «Tu intanto allarghi» in the Rencontre (which is identical to that of the Fiori), while the Giolito 6 ( 1553 ) variant reads «Tu mentre allarghi». Finally, s. I6 (by di Costanzo) reads at v. I 4 in the Rencontre: «Le pene uguali fian, diversi i chiostri» (identical to the Fiori version), while in the seventh Giolito volume of 1556 , the same verse reads «In forte ne verran diversi chiostri».

22. Verse 2 reads «a Cipri» in the Rencontre and Giolito vol. I, but «in Cipri» in the Fiori. Similarly, v. I 2 reads «Man, che l'acerbe piaghe» in the Rencontre and Giolito I, but «Tu man, ch'acerbe piaghe» in the Fiori. Finally, v. I 3 reads «Mitighi, e addolci» in the Rencontre and Giolito I, but «Fai care, e dolci» in the Fiori.

23. See De le rime di diversi nobili poeti toscani, raccolte da M. Dionigi Atanagi. Libro primo, Venice, Lodovico Avanzo, i 565 and Rime di Francesco Coppetta di Beccuti, Venice, Guerra fratelli, i 580.

24. The Rime ( 1580 ) versions contains these variants: v. 2 «un sottil velo»; v. 7 «Con providenza eterna»; v. 9 "Gran segni fur de la tua gran possanza»; and v. I I «Nascer quivi》. The Rencontre version, however, differs from the Atanagi version at v. 5 «Dar lege»; v. Io «tu Dio»; v. I I 


\section{JoAnn Dellaneva}

«Nascer homo»; and v. I 3 «Ch'io n'ol sò din». These discrepancies between the Atanagi version and the Rencontre transcription cannot easily be explained; it is possible that the Rencontre compiler had access to yet another version of the poem, perhaps in manuscript.

25. See on this point François Lecercle, La Fabrique du texte: les commentaires du Canzoniere de Pétrarque à la Renaissance, in Le Texte et ses représentations, Paris, P.E.N.S., I987, pp. 167-80, especially p. I 7 I.

26. See on this point Fedi, La Memoria della poesia cit., pp. 258-61, which shows how Bembo's poems in the first Giolito volume are organized in such a fashion; see also Giuliano Tanturli, Una raccolta di rime di Giovanni della Casa, «Studi di filologia italiana», 39 (I98I), pp. I 59-83, which postulates a mini-canzoniere from the placement of Della Casa's poems in the fourth Giolito volume.

27. See Erika Milburn, 'Come scultor che scopra / grand'arte in piccol'opra': Luigi Tansillo and a Miniature Canzoniere in the Rime diversi of 1552, «Italian Studies», 56 (2001), pp. 4-29. 


\section{APPENDIX ONE}

Anonymous annotations in Oewres de Philippes [sic] Des Portes, Lyon, Jaques [sic] Roussin, I 593, (Lyon, Bibliothèque municipale, Rés. 800 728). The location of the annotation is designated by the two columns at the left, indicating the page and poem number, along with the incipit of the poem in question. The actual handwritten annotation is given in the center column. The information to the right indicates to which anthology the annotator is referring and the incipit of the corresponding Italian poem.

\section{Le Premier Livre des Amours de Diane}

\begin{tabular}{|c|c|c|}
\hline I 2 r 44: $O$ songe beureux & «Voy Domincio Veniero pag 72» & Fiori $72 \mathrm{v}$ : Ove fugge crudele? \\
\hline I 2 r 45 : Je me travaille & «Voy Tibaldeo I 75» [crossed out] & Se mentre \\
\hline I $2 \mathrm{~V} 48$ : Les premiers jours & $\begin{array}{l}\text { «oy Angelo di Costanzo } \\
\text { pag } 7 \mathrm{~B} »\end{array}$ & Fiori $7 \mathrm{r}$ : Novo pensier \\
\hline I 5 r 58: J'ay long temps & «Voy Lod. Domenichi pag 207» & Fiori $207 \mathrm{r}$ : Io che solco \\
\hline I6r 62: Madame apres & $\begin{array}{l}\text { «mité de Angelo Costanzo } \\
\text { pag 4» [crossed out] }\end{array}$ & Fiori 4 r: Poi che voi \\
\hline I7v 68: J'ay tant suyvi & $\begin{array}{l}\text { «Tibaldeo pag Ior [crossed } \\
\text { out]»» } \\
(=\operatorname{Div} . A m .20) \text { «son I O2» }\end{array}$ & Già de la vita \\
\hline
\end{tabular}

Le Second Livre des Amours de Diane

4or 2: Arreste un peu

43r го: Hé ne suffit-il

43r i i: Si le mari

44r I 3: Amour de sa main

45V I 5: Yeux, qui guidez.

48v 23: Belle \& guerriere

48v 24: Chassez de vostre

49v: Celle que j'aime

Gor 44: Cent et cent fois

6Iv 48: Quand nous aurons

68r 70: On verra defaillir

\section{Les Amours d'Hippolyte \\ 7 IV I: Icare est cheu \\ 74r Iо: Amour qui vois \\ 88r 30: Six jours? \\ 88v 32: Deux clairs \\ 9IV 35: O mon coeur}

«Voy Angelo di Costanzo pag I 2 Fiori r 2r-v: Occhi, che fia B» [crossed out]

«Teb. I I 4 »

«Tebal. 55»

«Voy Gio-Bat. Marino pag 2»

«Imité de Guidiccioni pag I 82»

«Giovanni Mozarello pag 85»

«Tibaldeo son. I 3"

«Voy Dominico Veniero pag 72»

«Voy Angelo di Costanzo pag 9"

«Prins d'Angelo di Costanzo»

«Angelo di Costanzo pag I B»

Lasso non basta

S'el zoppo

Del petto mio

Fiori I $82 \mathrm{r}$ : Perdonnimi ${ }^{2}$

G I ( 1 546) 85: O bella man

Non serrano $i$ capei

Fiori $72 \mathrm{r}-\mathrm{v}$ : Abi chi mi rompe

Fiori 9 r-v: Se talhor la ragion

Fiori 4r: Poi che voi

Fiori Iv: Mancheran prima

«Prins de Sannazare pag I 32»

«Tibaldeo sonetto I66»

[near last verse:] «I 5 2»

«Antonio Rainieri pag 30»

(= Div. Am. 2I)

«Tibaldeo sonnetto I I 8 » [heavily crossed out]

«Voy incerti autori I 24» [heavily G2 (I 547) I 24r: O misere crossed out]
Fiori I 3 IV-I $32 \mathrm{r}$ : Icaro cadde A che contra

Non più saette

Fiori zor-v: Pacini, allor

Di vaghi occhi

fatiche 
93v 43: Avoir pour
97r 5 1: Sommeil qui
[marked 93r] (=Diane 2)
I02r 68: Souci chaud
I03v 73: Sommeil, paisible

Io4r 76: Le tyran
«Voy Pietro Barignano»

«Voy Andrea Navagero pag 99»

[crossed out]

«Gio Della Casa son 8»

«Andrea Navagero pag 99»

«Voy Gio B. Marino pag 3 I»

[crossed out]

«Angelo di Costanzo» [heavily Fiori 8v-9r: Non con tanta ira crossed out]
Fiori $233 \mathrm{v}-234 \mathrm{r}$ : Breve riposo or GI (I 546) 23

GI ( I 546) 99: Sonno, ch'a le

«B. Tasso lib 2 pagina I 34 » Se come o Dio

Cura che di timor

Gi (I 546) 99: Sonno, ch'a le $O$ del silentio figlio

Cléonice - Dernières Amours

I 7 r I I: Si trop en vous

«Voi Angelo di Costanzo pag 2» «Dominico Veniero pag $74 \mathrm{~B}$ »

Fiori Iv-2r: Chiaro mio sol

I 24V 35: Pource que je

«Voy V. Colonna pag 274»

Fiori $74 \mathrm{v}$ : V'amo donna

I $25 \mathrm{~V}$ 39: O miserable yeux

I 26v 40: Je pars

«Prins d'Angelo di Costanzo

Fiori 274 r-v: Occhi l'usanza

pag I०B»

I 26v: Que sera-ce

«Angelo di Costanzo pag I 2» Fiori I 2r-v: Occhi che fia? [crossed out]

I 27V 43: Demain j'espere

«Voy Fran. Maria Molza pag 9I Fiori 91 r-v: Doman vedrò

$\mathrm{B} »$

I 28v 46: Echo, nymphe

«Ce sonet est entierement pris de Fiori I42V-I43r: Già ninfa Amaltheo»

[very heavily crossed out]

I 29r 47: La garnison

«Ce sonnet est entierement pris Fiori 2 I6r: E si folta la schera du Tansille»

«Dominico Veniero pag 72»

I 29V 49: Je porte plus

«Voy Tibaldeo son I 3, 99»"

Fiori 72 r: Non ba tante

Non seranno i capei

Se avien ch'el ciel

I 36v 69: $M a$ belle et chere

I 39V 80: Espoir faux

«Voy B. Tasso pag 68 B»

«Bernardo Tomitano pag 49»

«Ce sonnet est entierement pris des Amours de Bernardo Tasso au liv. pag. 87»

Diverses Amours

26or 26: Frisez vos blonds «Tibaldeo pag 26I» ${ }^{4}$

Io ti abandono

Masquerades

$305 \mathrm{v}$ : Stances de la chasse «Del Bernia»

Berni: Caccia di Amore

Epitaphes (Regrets funebres sur la mort de Diane)

3 I 8v 3: O peu durable «Voy Giacomo Cencio pag 54»

G2 (I 547) 54r: O d'bumana

beltà

3igr 5: Comme on voit

«Giovanni Guidiccioni pag I 53»

Fiori i 53 r: Come da dense

Oeuvres chretiennes (Sonnets spirituels)

328v I: Depuis le triste «Imité de celuy del Molza

pag 90»

329v 6: Chargé de maladie «Tiré d'Annibal Caro pag. I 7》

Fiori 9ov: Anni vent'uno

Fiori I 7 r-v: Egro già 


\section{Reading Desportes through the Italians}

330r 8: Si mes ans 330v Io: Tourne un peu 332v 17: Quand miroir $332 \mathrm{~V}$ I 8: Je regrette
«Luigi Tansillo pag 224»

«Bernardo Tasso lib 2 pag 89» «Voy Vinc. Martelli pag 265 B» «Voy Bembo pag 239»
Fiori 224 r-v: Se di quei di A te pur torno

Fiori $265 \mathrm{v}$ : Or che con gli occhi Fiori 239r: Alto Re

I. The reference to Tebaldeo's sonnet \#IOI is clearly erroneous and corrected by the second annotation.

2. Vianey, misreading the notation as «I 52 » not «I 82 », saw here a reference to Guidiccioni’s poem Fidi specchi, though he admits this would be a very distant imitation.

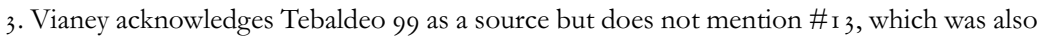
noted in the Lyonnais annotations.

4. Vianey claims that this sonnet is a translation of Tebaldeo's poem \#262 (actually \#263), A vostra posta, which it does indeed resemble, especially at the pointe. However, \#26I is related thematically to that poem, forming part of a longer series in the collection, and thus bears some similarities to Diverses Amours \#26, as suggested by the Lyonnais annotator.

\section{APPENDIX TWO}

List of poems and their Italian counterparts in Rencontre. An asterisk $\left(^{*}\right)$ signals that there are significant variant in other anthology editions for this source.

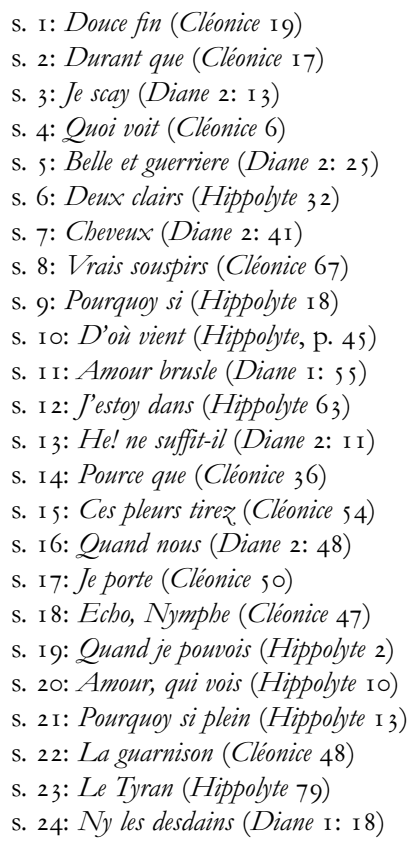

S'amate almo, DI Costanzo, Fiori 23 Mentrio scrivo, *DI Costanzo, Fiori 24 Hanno ben, *Amanio, G2 ( I 547, I ${ }^{\text {st }}$ ): $168 \mathrm{v}$

Chi vede, Di Costanzo, Fiori 44

$O$ bella man, *Mozzarello, Gi: 87

Duo vaghi, Tebaldeo, Opere i I 8

O chiome, Tebaldeo, Opere 106

Itene o miei, Fiorentino, Fiori 549

A che presti, Tebaldeo, Opere 36

Deh! perchè, Tebaldeo, Opere 48

Si dolce, Tebaldeo, Opere 35

Gionto nel, Tebaldeo, Opere 94

Lasso non basta, Tebaldeo, Opere I I 4

V'amo Donna, Veniero, Fiori i 85

Poi c'bai del sangue, DI Costanzo, Fiori 47

Poiche voi, * ${ }^{\mathrm{DI}}$ Costanzo, Fiori $2 \mathrm{I}$

Non hà, Veniero, Fiori I 80

Già Ninfa, *Amalteo, Fiori 306

Fù tempo, Tebaldeo, Opere 5

A che contra, Tebaldeo, Opere 166

A che cieco, Tebaldeo, Opere 122

E si, Tansillo, Fiori 473

Non con, di Costanzo, Fiori 32

Né di selvaggio, Gesualdo, Gi: 32 


\section{JoAnn Dellaneva}
s. 25: O lict! (Diane I: 7)
s. 26: Celle que (Diane 2: p. 239)
s. 27: Espouventable Nuict (Hippolyte 7I)
s. 28: Si le mary (Diane 2: I 2)
s. 29: Espoir faux (Cléonice 80)
s. 30 : Cent fois (Cléonice 63)
s. 3 I: Comme un chien (Div. Am. 25)
s. 32: Je pars (Cléonice 4I)
s. 33: Que sera-ce (Cléonice, p. 6o)
s. 34: Non non (Div. Am. 4)
s. 35: Si l'outrageuse (Cléonice 94)
s. 36: O peu durables (Epitaphes 3)
s. 37: Comme on voit (Epitaphes 5)
s. 38: Seigneur preste (Son. Sp. 5)
s. 39: Chargé de maladie (Son. Sp. 6)
s. 40: Sur les abymes (Son. Sp. 7)
s. 4I: Si mes ans (Son. Sp. 8)
s. 42: Helas! (Son. Sp. I I)
s. 43: De foy (Son. Sp. I s)

\author{
Letto, se, Tebaldeo, Opere is \\ Abi chi, Veniero, Fiori I 8 I \\ Orrida notte, Tansillo, Fiori 488 \\ S'el zoppo, Tebaldeo, Opere 55 \\ Speme che, *Tomitano, Fiori 20 \\ S'alcuna volta, DI Costanzo, Fiori 20 \\ Come fido, B. Tasso, Fiori 174 \\ Parto, di Costanzo, Fiori 36 \\ Occhi, che, di Costanzo, Fiori 40 \\ Come soffrir, Tebaldeo, Opere 2 I I \\ Poi che, B. Tasso, Fiori 175 \\ O d'humana, *CENCIO (= CARO), G2: $54 \mathrm{r}$ \\ Come da, Guidiccioni, Fiori 328 \\ Come Dio, Parabosco, G2: i 76 r \\ Carco [Egro] già, CARo, Fiori 50 \\ Locar sovra, *CoppetTA, Atanagi i: $54 \mathrm{r}$ \\ Se di quei, Tansillo, Fiori 49I \\ Signor, se miri, Molza, Fiori 226 \\ Da speme, Dal Pero, G2: ioov
}

